\title{
3,3'-Diiodothyronine Production, a Major Pathway of Peripheral Iodothyronine Metabolism in Man
}

\author{
Laurence A. Gavin, Margaret E. Hammond, James N. Castle, and Ralph R. \\ CAVAlieri, Medical and Nuclear Medicine Services, Veterans Administration \\ Hospital and Department of Medicine and Radiology, University of California, \\ San Francisco, California 94121
}

\begin{abstract}
A B S T R A C T 3,3'-Diiodothyronine $\left(3,3^{\prime}-\mathrm{T}_{2}\right)$ has been detected in human serum and in thyroglobulin. However, no quantitative assessment of its clearance rate $(\mathrm{CR})$, production rate (PR), or of the importance of extrathyroidal sources of $3,3^{\prime}-\mathrm{T}_{2}$ relative to direct thyroidal secretion is yet available. This study examines these parameters in seven euthyroid subjects, and in eight athyreotic subjects $(\mathrm{H})$ eumetabolic due to thyroxine therapy $\left(\mathrm{HT}_{4}\right)(n=5)$ or triiodothyronine replacement $\left(\mathrm{HT}_{3}\right) \quad(n=3)$. A highly specific radioimmunoassay for the measurement of $3,3^{\prime}-T_{2}$ in whole serum was developed. Serum $3,3^{\prime}-\mathrm{T}_{2}$ concentrations were (mean $\pm \mathrm{SD}$ ) $6.0 \pm 1.0 \mathrm{ng} / 100 \mathrm{ml}$ in 13 normal subjects, $9.0 \pm 4.6 \mathrm{ng} / 100 \mathrm{ml}$ in 25 hyperthyroid patients, and $2.7 \pm 1.1 \mathrm{ng} / 100 \mathrm{ml}$ in 17 hypothyroid patients. The values in each of the latter two groups were significantly different from normal. 3,3'- $\mathrm{T}_{2}$ was detected regularly in normal concentrations in 11 hypothyroid patients eumetabolic by treatment with synthetic $T_{4}$, in 10 eumetabolic patients suffering from nonthyroidal systemic illness, and in 2 subjects with elevated serum $\mathrm{T}_{4}$-binding globulin. The $3,3^{\prime}-\mathrm{T}_{2} \mathrm{CR}$ was assessed from data acquired from the ${ }^{125} \mathrm{I}-3,3^{\prime}-\mathrm{T}_{2}$ constant infusion technique. The $3,3^{\prime}-\mathrm{T}_{2}$ PR was calculated from $\mathrm{CR}$ and serum concentration of $3,3^{\prime}-\mathrm{T}_{2}$ determined by radioimmunoassay. In the $\mathrm{HT}_{4}$ subjects the $3,3^{\prime}-\mathrm{T}_{2} \mathrm{CR}$ averaged $840 \pm 377$ liters/day and $3,3^{\prime}-\mathrm{T}_{2}$ PR $33.9 \pm 12.5$ $\mu \mathrm{g} /$ day. These results were not significantly different from those in the control group: $3,3^{\prime}-\mathrm{T}_{2}$ CR $628 \pm 218$ liters/day and 3,3'- $\mathrm{T}_{2}$ PR $39.8 \pm 19.8 \mu \mathrm{g} /$ day (all corrected to $70 \mathrm{~kg}$ body $\mathrm{wt}$ ). In addition to $3,3^{\prime}-\mathrm{T}_{2} \mathrm{PR}$, $\mathrm{T}_{3}$, and reverse triiodothyronine $\left(\mathrm{rT}_{3}\right) \mathrm{PR}$ were determined in three of the $\mathrm{HT}_{4}$ subjects. In each case studied, the $3,3^{\prime}-T_{2}$ PR was close to the combined tri-
\end{abstract}

This work was presented in part before the American Federation for Clinical Research, Washington, D. C., May 1977 and published in abstract form (1977. Clin. Res. 25: 294.).

Received for publication 6 September 1977 and in revised form 16 January 1978. iodothyronine $\left(\mathrm{T}_{3}+\mathrm{rT}_{3}\right)$ PR. The mean molar ratio of $\mathrm{T}_{2} \mathrm{PR} /\left(\mathrm{T}_{3}+\mathrm{rT}_{3}\right) \mathrm{PR}$ was $1.08 \pm 0.10$. The results obtained in the $\mathrm{HT}_{4}$ subjects indicate that the production of $3,3^{\prime}-T_{2}$ is a major route of $T_{4}$ metabolism. The combined studies of $3,3^{\prime}-\mathrm{T}_{2}, \mathrm{~T}_{3}$ and $\mathrm{rT}_{3} \mathrm{PR}$ in the $\mathrm{HT}_{4}$ subjects indicate that both $\mathrm{T}_{3}$ and $\mathrm{rT}_{3}$ are major precursors of $3,3^{\prime}-\mathrm{T}_{2}$. In the $\mathrm{HT}_{3}$ subjects, the conversion of $T_{3}$ to $3,3^{\prime}-T_{2}$, determined as the molar ratio of $3,3^{\prime}$ $\mathrm{T}_{2} \mathrm{PR}$ to $\mathrm{T}_{3} \mathrm{PR}$, ranged from 0.36 to 0.92 , providing further evidence that $T_{3}$ is a precursor of $3,3^{\prime}-T_{2}$. From the close agreement between the mean values for 3,3'$\mathrm{T}_{2} \mathrm{PR}$ in the euthyroid and $\mathrm{HT}_{4}$ group it is concluded that most, if not all of the $3,3^{\prime}-T_{2}$ produced in normal humans is derived by extrathyroidal conversion from $\mathrm{T}_{3}$ and $\mathrm{rT}_{3}$.

\section{INTRODUCTION}

The presence of $3,3^{\prime}$-diiodothyronine $\left(3,3^{\prime}-T_{2}\right)^{1}$ in the thyroid gland and the plasma of the rat was demonstrated originally by Roche et al. (1). Subsequently, the same group showed that radioiodine-labeled 3,5,3'triiodothyronine $\left(\mathrm{T}_{3}\right)$ and 3,3',5'-triiodothyronine (reverse $T_{3}\left[\mathrm{rT}_{3}\right]$ ) were converted to $3,3^{\prime}-\mathrm{T}_{2}$ in the rat (2). Flock et al. $(3,4)$ reported similar findings in the intact dog. Chopra et al. (5) have recently presented evidence in rat liver homogenates that the conversion of $\mathrm{rT}_{3}$ and of $\mathrm{T}_{3}$ to $3,3^{\prime}-\mathrm{T}_{2}$ is enzymatic in nature.

Three groups have described radioimmunoassays for $3,3^{\prime}-T_{2}$ in normal human serum, although the reported levels do not agree (6-8). No quantitative estimates have been made, however, of the turnover of $3,3^{\prime}-\mathrm{T}_{2}$ in humans. In an early study, Stanbury and Morris (9) using ${ }^{131} \mathrm{I}-3,3^{\prime}$-D, L- $\mathrm{T}_{2}$ administered to nor-

\footnotetext{
${ }^{1}$ Abbreviations used in this paper: ANS, 8-anilino-L-naphaline sulfonic acid; $\mathrm{C}$, control group; $\mathrm{CR}$, clearance rate; $\mathrm{CV}$, coefficient of variance; $\mathrm{H}$, hypothyroid group; $\mathrm{PR}$, production rate; 3, 3'- $\mathrm{T}_{2}, 3,3^{\prime}$-L-diiodothyronine; $\mathrm{T}_{3}$, triiodothyronine; $\mathrm{rT}_{3}$, reverse $T_{3} ; T_{4}$, thyroxine; TBG, thyroxine-binding globulin.
} 
mal subjects in a single bolus injection, found extremely rapid disappearance of tracer from plasma and accumulation of radioiodide in the urine, indicating a high rate of deiodination of this compound.

The present study was initiated to assess the absolute production rate of $3,3^{\prime}-\mathrm{T}_{2}$ in man, using the technique of constant tracer infusion to estimate plasma clearance and a specific radioimmunoassay to measure plasma concentration of this substance. In addition to studies of subjects with intact thyroid glands, measurements of $3,3^{\prime}-\mathrm{T}_{2}$ kinetics were done in athyreotic patients who were maintained eumetabolic on L-thyroxine $\left(T_{4}\right)$ to determine the importance of extrathyroidal sources of $3,3^{\prime}-\mathrm{T}_{2}$ relative to direct thyroidal secretion. In some of the athyreotic subjects on $T_{4}$ therapy, turnover studies of $\mathrm{T}_{3}$ and $\mathrm{rT}_{3}$ were performed as well. In three additional cases receiving $T_{3}$ as maintenance therapy, $\mathrm{T}_{3}$ and $3,3^{\prime}-\mathrm{T}_{2}$ kinetics were determined. These studies allowed an assessment of the relative contributions of $T_{3}$ and of $\mathrm{rT}_{3}$ as immediate precursors of $3,3^{\prime}-\mathrm{T}_{2}$ in humans.

\section{METHODS}

The subjects participating in this investigation were from the outpatient service of the San Francisco Veterans Administration Hospital. All subjects gave written consent, having been informed of the purpose and nature of the study. Seven male euthyroid control subjects included four normal volunteers and three patients with mild nonthyroidal, nonsystemic illnesses. The eight athyreotic adult males were eumetabolic by clinical and laboratory criteria at the time of study. Five subjects were receiving full replacement doses of $\mathrm{L}_{-} \mathrm{T}_{4}$ (Synthroid, Flint Laboratories, Deerfield, Ill.) and three were

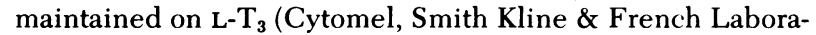
tories, Philadelphia, Pa.). None of the patients was taking any drug known to interfere with normal thyroid function or to affect the metabolism of thyroid hormones. The mean $\mathrm{T}_{4}$ replacement dose in the athyreotics was $145 \mu \mathrm{g} /$ day.

Radioimmunoassay of 3,3'- $T_{2}$. Unlabeled $3,3^{\prime}-\mathrm{L}-\mathrm{T}_{2}$ and the various other thyroid hormone analogues and derivatives were obtained through the courtesy of Dr. Eugene Jorgensen, University of California, San Francisco, Calif. The ${ }^{125} \mathrm{I}-3,3^{\prime}-\mathrm{T}_{2}$ (labeled presumably in the $3^{\prime}$-position) was prepared from 3,3'-L- $\mathrm{T}_{2}$ by Abbott Laboratories, North Chicago, Ill. Specific activity ranged from 250 to $350 \mu \mathrm{Ci} / \mu \mathrm{g}$. At the time of use, each lot of labeled tracer was analyzed for radiochemical purity by Sephadex G-25 column chromatography (by the method described below) and was found to contain $<5 \%$ of labeled iodide and $<1 \%$ of labeled $\mathrm{rT}_{3}$. A conjugate of $3,3^{\prime}-\mathrm{T}_{2}$ and $3,3^{\prime}-\mathrm{T}_{2}$ - bovine serum was prepared by the method of Gharib et al. (10). The carbodiimide (1-cyclohexyl3-carbodiimide metho- $p$-toluene-sulfonate) was obtained from Aldrich Chemical Co., Inc., Milwaukee, Wis., and dimethylformamide from Fisher Scientific Co., Pittsburgh, Pa. Antiserum was harvested from rabbits immunized with the 3,3'$\mathrm{T}_{2}$-bovine serum albumin conjugate emulsified in complete Freund's adjuvant (Miles Laboratories, Inc., Elkhart, Ind.) and pertussis vaccine (Eli Lilly and Company, Indianapolis, Ind.). The antiserum selected for the present study bound $30-35 \%$ of tracer amounts of radioactive $3,3^{\prime}-\mathrm{T}_{2}$ in a final dilution of $1: 10,000$. The binding of ligand to serum proteins was inhibited by 8-anilino-L-naphthaline sulfonic acid (ANS), supplied by Eastman Kodak Co., Rochester, N. Y.
To determine the need for ANS in our assay we compared the percent $(\% \mathrm{~B} / \mathrm{T})$ of ${ }^{125} \mathrm{I}-3,3^{\prime}-\mathrm{T}_{2}$ bound by a fixed concentration of antiserum in barbital buffer $(0.07 \mathrm{M}$ barbital, $\mathrm{pH}$ 8.6) with that bound in iodothyronine-free serum (11). In the absence of ANS, antibody bound only $8-10 \%$ of ${ }^{125} \mathrm{I}-3,3^{\prime}-\mathrm{T}_{2}$ in serum compared to $50-60 \%$ in barbital. From a series of experiments utilizing from 75 to $500 \mu \mathrm{g}$ ANS per tube, we determined that $450 \mu \mathrm{g}$ per tube allowed optimum binding $(30 \%)$ of ${ }^{125} \mathrm{I}-3,3^{\prime}-\mathrm{T}_{2}$ by our antiserum in iodothyronine-free serum.

Serum $3,3^{\prime}-\mathrm{T}_{2}$ was determined in unextracted serum samples. The various reagents were added in the following order: (a) $200 \mu \mathrm{l}$ of test sample; (b) $300 \mu \mathrm{l}$ of $2 \%$ normal rabbit serum in barbital buffer (0.07 M barbital, pH 8.6); (c) 100 $\mu \mathrm{l}(450 \mu \mathrm{g})$ of ANS; (d) $100 \mu \mathrm{l}(5 \mathrm{pg})$ of ${ }^{125} \mathrm{I}-3,3^{\prime}-\mathrm{T}_{2} ;(e) 100$ $\mu \mathrm{l}$ of $1 / 1,250$ diluted $\mathrm{T}_{2}$-binding antiserum. The samples were incubated for $24 \mathrm{~h}$ at $4^{\circ} \mathrm{C}$. A sufficient quantity $(50 \mu \mathrm{l})$ of previously titered goat anti-rabbit gamma globulin (Antibodies Inc., Davis, Calif.) was then added and the mixture further incubated for $24 \mathrm{~h}$ at $4^{\circ} \mathrm{C}$. The bound precipitate was separated by centrifugation and aspiration of the supernate. Antibody-bound radioactivity was determined in an automatic well counter. Standards containing stable $3,3^{\prime}-\mathrm{T}_{2}(0.5-100 \mathrm{ng} /$ $\mathrm{dl}$ ) were prepared in iodothyronine-free serum (11) and were processed by the same method. A standard curve was constructed as percent bound ${ }^{125} \mathrm{I}-3,3^{\prime}-\mathrm{T}_{2}$ vs. concentration of $3,3^{\prime}-\mathrm{T}_{2}$. The $3,3^{\prime}-\mathrm{T}_{2}$ concentration in $0.2 \mathrm{ml}$ of test serum was read from the standard curve and the results were expressed in nanograms of $3,3^{\prime}-\mathrm{T}_{2} / 100 \mathrm{ml}$. Total serum $\mathrm{T}_{3}$ and $\mathrm{rT}_{3}$ were measured by radioimmunoassay as previously described (12). Total serum $\mathrm{T}_{4}$ and free $\mathrm{T}_{4}$ index were determined by a competitive binding assay (13).

Preparation of $3,3^{\prime}-T_{2}$ conjugates. ${ }^{125} \mathrm{I}-3,3^{\prime}-\mathrm{T}_{2}$ was injected into the inferior vena cava of an adult male Sprague-Dawley rat. Bile was collected via a biliary cannula for $4 \mathrm{~h}$ postinjection. The radioactive components of the bile were separated by thin-layer chromatography of $20 \times 20$-cm glass-fiber sheets (Gelman Instrument Co., Ann Arbor, Mich.). Chromatographs were developed in butanol-dioxane-2 $\mathrm{N}$ ammonia, 4:1:5 (vol/ $\mathrm{vol} / \mathrm{vol}$ ), at $25^{\circ} \mathrm{C}$ for $1 \frac{1}{2} \mathrm{~h}$, and dried in a stream of nitrogen. The radioactive bands were located by autoradiography of the dried chromatogram and the various components eluted from the chromatogram in methanol-ammonia (99:1). The 3,3'$\mathrm{T}_{2}$ glucuronide and sulfo-conjugate zones were identified by enzymatic hydrolysis using glucuronidase (Worthington Biochemical Corp., Freehold, N. J.) and Mylase-P (ICN Pharmaceuticals, Inc., Life Sciences Group, Cleveland, Ohio), respectively $(14-16)$.

Constant-infusion 3,3'- $T_{2}$ studies. Subjects were hospitalized on a metabolic ward for the duration of the study. Thyroidal radioiodine uptake was minimized in all euthyroid subjects by giving a saturated solution of potassium iodide orally, 10 drops every $8 \mathrm{~h}$ before and during the study. ${ }^{125} \mathrm{I}-3,3^{\prime}-\mathrm{T}_{2}$, diluted in $1 \%$ human serum albumin in normal saline to a concentration of $8 \mu \mathrm{Ci} / \mathrm{ml}$, was sterilized by Millipore filtration (Millipore Corp., Bedford, Mass.) before administration to the subjects. A total dose of $200 \mu \mathrm{Ci}$ $(25 \mathrm{ml})$ was administered by intravenous infusion over $8 \mathrm{~h}$ at a constant rate $(3.1 \mathrm{ml} / \mathrm{h})$ in each subject. The constant infusion was given with a Harvard Infusion Pump (Harvard Apparatus Co., Inc., Millis, Mass.). The accuracy of the rate of infusion was checked on several occasions in control runs by measuring $\mathrm{H}_{2} \mathrm{O}$ infusion into a graduated cylinder over $8 \mathrm{~h}$ and also during the actual infusions by recording the volume infused per hour from the graduated infusion syringe. We always prepared $30 \mathrm{ml}$ of tracer solution, as extra volume was needed to fill the tubing connecting the pump (syringe) with the patient. Aliquots for standards were 
taken from the solution remaining in the tubing at the completion of the infusion. Samples of blood were obtained at time 0 and every $2 \mathrm{~h}$ during the infusion.

$T_{3}$ and $r T_{3}$ kinetics studies. ${ }^{131} \mathrm{I}-\mathrm{T}_{3}$ was obtained from Amersham Corp. (Arlington Heights, Ill.) at a specific radioactivity of $\cong 40 \mu \mathrm{Ci} / \mu \mathrm{g}$. ${ }^{125} \mathrm{I}_{-} \mathrm{rT}_{3}$ was supplied by Abbott Laboratories at a specific radioactivity of $500 \mu \mathrm{Ci} / \mu \mathrm{g}$. Before administration to human subjects, a mixture of ${ }^{131} \mathrm{I}-\mathrm{T}_{3}$ and ${ }^{125} \mathrm{I}$ $\mathrm{rT}_{3}$, diluted in $1 \%$ human serum albumin-normal saline, was sterilized by Millipore filtration. Tracer doses of ${ }^{131} \mathrm{I}-\mathrm{T}_{3}(100$ $\mu \mathrm{Ci})$ and ${ }^{125} \mathrm{I}-\mathrm{rT}_{3}(200 \mu \mathrm{Ci})$, in an accurately measured volume, were injected intravenously. Samples of blood were obtained at $15,30,60 \mathrm{~min}$ and $2,4,6,12 \mathrm{~h}$, and every $12 \mathrm{~h}$ thereafter until $72 \mathrm{~h}$ after the doses were administered.

In all tracer studies, dose standards were prepared by adding aliquots of tracer doses to undiluted pooled normal serum. These standards were processed in an identical manner to the plasma samples.

Analysis of sera from kinetics studies. Multiple serum samples, collected during the ${ }^{125} I-3,3^{\prime}-\mathrm{T}_{2}$ infusion studies, were analyzed by column chromatography employing Sephadex G-25F, by a modification of the method described by Green (17). A column of Sephadex G-25F, bed volume $2.05 \times 25 \mathrm{~cm}$, was equilibrated with $0.5 \mathrm{M} \mathrm{NaCl}-0.054$ $\mathrm{N} \mathrm{NaOH} \mathrm{(pH} \mathrm{11.3).} \mathrm{Samples} \mathrm{and} \mathrm{standards}(3 \mathrm{ml})$ were diluted with an equal volume of diluent $(1.0 \mathrm{M} \mathrm{NaCl}$ in $0.2 \mathrm{M}$ phosphate buffer, $\mathrm{pH}$ 6.5) before application to the column. Iodoprotein, iodide, and ${ }^{125} \mathrm{I}-3,3,3^{\prime}-\mathrm{T}_{2}$ were eluted in succession by $0.005 \mathrm{M} \mathrm{NaCl}+0.1 \mathrm{~N} \mathrm{NaOH}, \mathrm{pH}$ 11.8. $20 \mathrm{mM}$ sodium metabisulfite was added to the equilibrating and eluting solution to minimize deiodination. From 140 to 160 fractions $(3 \mathrm{ml}$ each) were collected. Each fraction was counted $(10 \mathrm{~min})$ in an automatic well-type gamma counter (mean background $=40 \mathrm{cpm}$ ). Those fractions included in the ${ }^{125} \mathrm{I}-3,3^{\prime}-\mathrm{T}_{2}$ region (fractions $75-120$, approximately) were counted again for longer periods, up to $100 \mathrm{~min}$ each, to obtain a relative counting error of $3 \%$ or less.

An average of $98.2 \pm 4.7 \%$ (SD) of the total ${ }^{125} \mathrm{I}$ in samples and standards applied (40 runs) to the column was recovered in the eluate. Of the total ${ }^{125} \mathrm{I}$ in the standards prepared from the infusate, $86.6 \pm 7.5 \%$ was eluted as ${ }^{125} \mathrm{I}-3,3^{\prime}-\mathrm{T}_{2}$. The remainder of the ${ }^{125} \mathrm{I}$ was in the form of iodide and iodoprotein in approximately equal proportions. The mean ${ }^{125} \mathrm{I}-3,33^{\prime}-\mathrm{T}_{2}$ concentration in two or more samples taken during the steadystate was used in the determination of the clearance rate (CR).

${ }^{131} \mathrm{I}-\mathrm{T}_{3}$ and ${ }^{125} \mathrm{I}-\mathrm{r} \mathrm{T}_{3}$ were separated from other labeled components of serum by means of anion-exchange resin columns (Curtis Nuclear Corp., Los Angeles, Calif.) according to the method described by Nicoloff et al. (18). The experience of our laboratory with this method of analysis for ${ }^{131} \mathrm{I}-\mathrm{T}_{3}$ and ${ }^{125} \mathrm{I}_{-} \mathrm{rT}_{3}$ has been described (12). All samples and dose standards from a kinetics study were processed at the same time. For each tracer, the results are expressed as the percent of the injected dose per liter of serum.

Calculations. In the constant infusion $3,3^{\prime}-\mathrm{T}_{2}$ study the CR was calculated from the infusion rate divided by the steady-state serum concentration of ${ }^{125} \mathrm{I}-3,3^{\prime}-\mathrm{T}_{2}$ achieved during the infusion (12). The production rate (PR) was calculated from CR multiplied by the serum concentration of stable 3,3'$\mathrm{T}_{2}$ (mean of three to five samples taken during infusion). In each single injection $\left(\mathrm{T}_{3}\right.$ and $\left.\mathrm{rT}_{3}\right)$ study, the plasma disappearance curve for each tracer was fit to a three-exponential function by the method of least squares. From the $Y$-intercepts and slopes of the exponential components the CR was computed by the method of Tait (19). The production rate was calculated as described for $3,3^{\prime}-\mathrm{T}_{2}$.

Statistical methods. All results have been expressed as mean $\pm S D$. Statistical evaluations were performed by the unpaired Student's $t$ test (20).

\section{RESULTS}

\section{Radioimmunoassay for $L-3,3^{\prime}-T_{2}$}

Specificity. The reactivities of various compounds relative to $3,3^{\prime}-T_{2}$ were calculated on the basis of the molar amount that caused $50 \%$ inhibition of the binding of ${ }^{125} \mathrm{I}-3,3^{\prime}-\mathrm{T}_{2}$ to antibody (Table I). The monoiodothyronines, $3-\mathrm{T}_{1}$ and $3^{\prime}-\mathrm{T}_{1}$, demonstrated the greatest degree of cross-reactivity. $T_{4}$ and $T_{3}$ demonstrated negligible reactivity, whereas $\mathrm{rT}_{3}$ showed a cross-reactivity of $0.6 \%$. The calculated total contribution of $\mathrm{T}_{4}, \mathrm{~T}_{3}$, and $\mathrm{rT}_{3}$ was $<5 \%$ of the observed $3,3^{\prime}-\mathrm{T}_{2}$ concentration, based on the cross-reactivity values and the known concentrations of these iodothyronines in normal serum.

Analysis of the autoradiographic bands eluted from the thin-layer chromatograph of rat bile demonstrated the presence of two labeled conjugates. The eluted bands containing the conjugates represented $52 \%$ of the total biliary counts applied to the chromatograph. Enzymatic hydrolysis of these bands with $\beta$-glucuronidase and Mylase-P in separate experiments released ${ }^{125} \mathrm{I}-3,3^{\prime}-\mathrm{T}_{2}$. Before enzymatic hydrolysis there was no detectable binding by specific $3,3^{\prime}-\mathrm{T}_{2}$-binding antibody of the radioactive conjugates of $3,3^{\prime}-\mathrm{T}_{2}$. In control experiments it was determined that the enzymes did not affect the antibody binding of tracer.

Standard curve. Fig. 1 demonstrates a typical standard curve of $3,3^{\prime}-T_{2}$ radioimmunoassay. Significant inhibition of the binding of ${ }^{125} \mathrm{I}-3,3^{\prime}-\mathrm{T}_{2}$ to antiserum was evident with as little as $20 \mathrm{pg}$ of stable $3,3^{\prime}-\mathrm{T}_{2} / \mathrm{ml}$ serum $(4 \mathrm{pg} /$ tube $)$. The sensitivity of the assay was determined from $t$-test analyses of data from multiple standard curves performed in triplicate. The data were expressed as percent bound (mean $\pm \mathrm{SD}$ ) and the first point on each standard curve demonstrating a significant difference $(P<0.05)$ at $>2$ SD from the

TABLE I

Related Cross-Reactivity of Various Iodothyronines with 3,3'- $T_{2}$ Antiserum

\begin{tabular}{|c|c|}
\hline Compound & Relative cross-reactivity \\
\hline & $\%$ \\
\hline $\mathbf{L}-3,3^{\prime}-\mathbf{T}_{2}$ & 100.0 \\
\hline $\mathrm{L}-3-\mathrm{T}_{1}$ & 10.3 \\
\hline $\mathrm{D}, \mathrm{L}-3^{\prime}-\mathrm{T}_{1}$ & 7.3 \\
\hline L-rT ${ }_{3}$ & 0.6 \\
\hline $\mathrm{D}, \mathrm{L}-3^{\prime}, 5^{\prime}-\mathrm{T}_{2}$ & 0.3 \\
\hline $\mathrm{L}-\mathrm{T}_{3}$ & 0.07 \\
\hline Triac* & 0.046 \\
\hline $\mathrm{L}-3,5-\mathrm{T}_{2}$ & 0.014 \\
\hline $\mathrm{L}-\mathrm{T}_{4}$ & $<0.001$ \\
\hline Tetrac* & $<0.001$ \\
\hline
\end{tabular}

${ }^{*}$ Triac, 3,5,3'-L-triiodothyroacetic acid; Tetrac, 3,5,3',5'-Ltetraiodothyroacetic acid. 


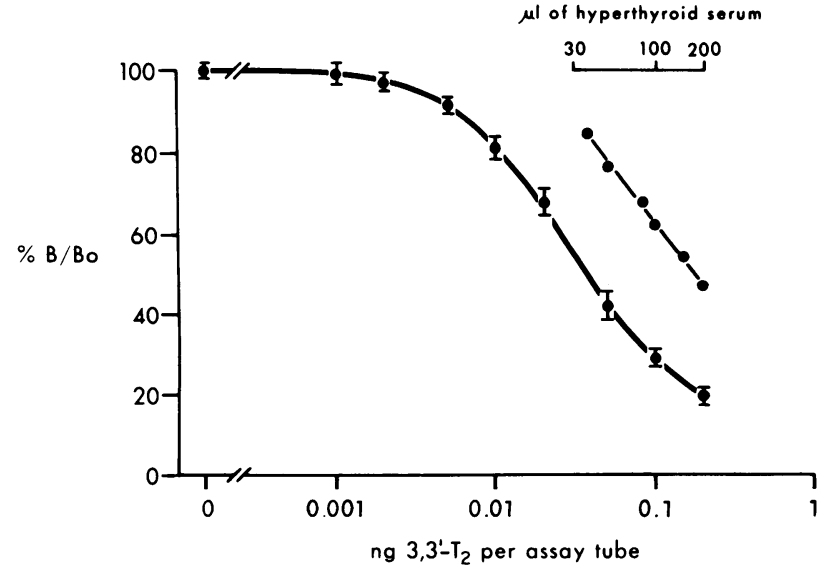

FIGURE 1 Standard curve for $3,3^{\prime}-\mathrm{T}_{2}$ radioimmunoassay and the effects of varying dilutions of serum from a hyperthyroid patient on the binding of ${ }^{125} \mathrm{I}-3,3^{\prime}-\mathrm{T}_{2}$ by antibody.

basal point was taken as the assay sensitivity. Fig. 1 also demonstrates that the binding curve of dilutions (with iodothyronine-free serum) of serum from a hyperthyroid patient was parallel to the standard curve.

Recovery. Treatment of sera with activated charcoal (11) demonstrated that $96-99 \%$ of the added ${ }^{125} \mathrm{I}$ $3,3^{\prime}-\mathrm{T}_{2}$ was removed by this procedure. To determine the recovery of $3,3^{\prime}-T_{2}$ in this assay, various amounts of stable $3,3^{\prime}-\mathrm{T}_{2}$ were added to sera from normal, hyperthyroid, hypothyroid subjects, and from euthyroid individuals with idiopathic elevation in $\mathrm{T}_{4}$-binding globulin (TBG). In 12 separate assays $3,3^{\prime}-\mathrm{T}_{2}$ concentration was determined before and after enrichment of samples with stable $3,3^{\prime}-\mathrm{T}_{2}$. A normal $(5.9 \mathrm{ng} / 100$ $\mathrm{ml})$ and a hypothyroid serum $(3.0 \mathrm{ng} / 100 \mathrm{ml})$ sample were enriched with $3.0 \mathrm{ng} / 100 \mathrm{ml}$. The percent recoveries were 112 and 100, respectively. A hyperthyroid $(10.0 \mathrm{ng} / 100 \mathrm{ml})$ and a high TBG serum $(5.0 \mathrm{ng} /$ $100 \mathrm{ml}$ ) sample were enriched with $9.0 \mathrm{ng} / 100 \mathrm{ml}$. The percent recoveries were 107 and 93 , respectively. The mean $3,3^{\prime}-T_{2}$ recovery from the series of experiments was $103 \%$.

Reproducibility. The intra- and interassay reproducibility was examined in samples with variable 3,3'$\mathrm{T}_{2}$ concentrations. The intra-assay coefficient of variation $(\mathrm{SD} /$ mean $\times 100)$ was $6.2 \%$. The mean coefficient of variation of 10 specimens, varying in $3,3^{\prime}-\mathrm{T}_{2}$ concentration from 2.0 to $9.0 \mathrm{ng} / 100 \mathrm{ml}$ and assayed in duplicate four times in different assays, was $11.6 \%$.

Serum 3,3'- $T_{2}$ concentration in health and disease. Table II presents data on serum $3,3^{\prime}-T_{2}$ concentration in normal subjects and patients with diverse levels of thyroid function as determined by clinical assessment and standard laboratory studies. The mean serum 3,3'$\mathrm{T}_{2}$ concentration in 13 healthy euthyroid subjects was

TABLE II

Serum 3,3'- $T_{2}, T_{4}, T_{3}$, and $r T_{3}$ Concentrations in Various Thyroid States

\begin{tabular}{crccc}
\hline Group & & Mean & SD & Range \\
\hline Control subjects $(n=13)$ & $3,3^{\prime}-\mathrm{T}_{2}, n g / 100 \mathrm{ml}$ & 6.0 & 1.0 & $4.5-7.8$ \\
& $\mathrm{~T}_{4}, \mu g / 100 \mathrm{ml}$ & 7.2 & 1.1 & $5.5-8.9$ \\
& $\mathrm{~T}_{3}, n g / 100 \mathrm{ml}$ & 103 & 15.1 & $82-125$ \\
& $\mathrm{rT}_{3}, n g / 100 \mathrm{ml}$ & 26 & 4 & $21-37$ \\
Hyperthyroidism $(n=25)$ & $3,3^{\prime} \mathrm{T}_{2}, n g / 100 \mathrm{ml}$ & $9.0^{*}$ & 4.6 & $3.0-21.0$ \\
& $\mathrm{~T}_{4}, \mu g / 100 \mathrm{ml}$ & $14.8 \ddagger$ & 2.4 & $12.0-18.5$ \\
& $\mathrm{~T}_{3}, n g / 100 \mathrm{ml}$ & $239 \ddagger$ & 98 & $129-500$ \\
Hypothyroidism $(n=17)$ & $\mathrm{rT}_{3}, n g / 100 \mathrm{ml}$ & $77 \ddagger$ & 33 & $41-160$ \\
& $3,3^{\prime} \mathrm{T}_{2}, n g / 100 \mathrm{ml}$ & $2.7 \ddagger$ & 1.1 & $<2.0-6.0$ \\
& $\mathrm{~T}_{4}, \mu \mathrm{g} / 100 \mathrm{ml}$ & $2.1 \ddagger$ & 0.7 & $<1.8-4.1$ \\
& $\mathrm{~T}_{3}, n g / 100 \mathrm{ml}$ & $62 \ddagger$ & 27 & $24-105$ \\
Hypothyroidism treated with & $\mathrm{rT}_{3}, n g / 100 \mathrm{ml}$ & $8 \ddagger$ & 4 & $<3-16$ \\
$\mathrm{~T}_{4}(n=1 \mathrm{l})$ & $3,3^{\prime}-\mathrm{T}_{2}, n g / 100 \mathrm{ml}$ & 5.3 & 1.5 & $3.3-8.5$ \\
& $\mathrm{~T}_{4}, \mu g / 100 \mathrm{ml}$ & 7.9 & 2.1 & $5.4-12.2$ \\
& $\mathrm{~T}_{3}, n g / 100 \mathrm{ml}$ & 88 & 15 & $64-119$ \\
& $\mathrm{rT}_{3}, n g / 100 \mathrm{ml}$ & 33 & 13 & $21-60$ \\
Patients with acute nonthyroidal & $3,3^{\prime}-\mathrm{T}_{2}, n g / 100 \mathrm{ml}$ & 4.8 & 2.7 & $2.0-9.4$ \\
systemic illness $(n=10)$ & $\mathrm{T}_{4}, \mu g / 100 \mathrm{ml}$ & 7.4 & 2.0 & $5.6-11.0$ \\
& $\mathrm{~T}_{3}, n g / 100 \mathrm{ml}$ & $49 \ddagger$ & 22 & $<10-87$ \\
& $\mathrm{rT}_{3}, n g / 100 \mathrm{ml}$ & $43 \S$ & 25 & $16-94$ \\
\hline & & & &
\end{tabular}

* Cf. normal $P<0.01$.

\& Cf. normal $P<0.001$.

$\S$ Cf. normal $P<0.05$. 
$6.0 \pm 1.0 \mathrm{ng} / 100 \mathrm{ml}$ with a range from 4.5 to $7.8 \mathrm{ng} / 100$ $\mathrm{ml}$. The mean serum $3,3^{\prime}-\mathrm{T}_{2}$ concentration in $25 \mathrm{un}$ treated hyperthyroid patients was significantly higher than in normal subjects $(P<0.01)$ but extended over a wide range from 3.0 to $21.0 \mathrm{ng} / 100 \mathrm{ml}$. In the 17 untreated hypothyroid patients the mean serum $3 ; 3^{\prime}-\mathrm{T}_{2}$ concentration was significantly lower than in normal subjects $(P<0.001)$. The mean serum $3,3^{\prime}-\mathrm{T}_{2}$ in 11 hypothyroid patients maintained eumetabolic on $\mathrm{L}_{\mathrm{T}} \mathrm{T}_{4}$ (100-200 $\mu \mathrm{g} /$ day) was not significantly different from the normal subjects. In 10 patients suffering from acute nonthyroidal systemic illness with decreased total serum $\mathrm{T}_{3}(49 \pm 22 \mathrm{ng} / 100 \mathrm{ml})$ and elevated $\mathrm{rT}_{3}(43 \pm 25$ $\mathrm{ng} / 100 \mathrm{ml}$ ), the mean $3,3^{\prime}-\mathrm{T}_{2}$ level was within the normal range. These patients had a variety of disorders: three acute hepatitis; three unstable angina; two infectious disorders; one postdiabetic ketoacidosis and one postgastrectomy for peptic ulcer disease. In two subjects with high serum TBG levels the $3,3^{\prime}-\mathrm{T}_{2}$ concentrations were within the normal range. There was no correlation between $3,3^{\prime}-\mathrm{T}_{2}$ concentration and serum $\mathrm{T}_{4}, \mathrm{~T}_{3}$, or $\mathrm{rT}_{3}$ in any of the groups.

Synthroid and Cytomel tablets ground into powder, dissolved in $0.05 \mathrm{M} \mathrm{NaOH}$, and diluted in iodothyronine-free serum, demonstrated $3,3^{\prime}-\mathrm{T}_{2}$ levels consistent with those anticipated from their respective assay cross-reactivities.

Analyses of stable $3,3^{\prime}-\mathrm{T}_{2}$ concentrations by radioimmunoassay in serum sample collected from controls and athyreotic subjects receiving $\mathrm{T}_{4}\left(\mathrm{HT}_{4}\right)$ or $\mathrm{T}_{3}\left(\mathrm{HT}_{3}\right)$ during the 8-h infusion period of the kinetics study revealed minimal variation in its concentration. All of the samples were stored frozen for an adequate period of time after the tracer infusion period to allow for radioactive decay. The coefficients of variation $(\mathrm{CV})$ of samples collected during the 8-h period for each group studied were: controls $(n=7) 11.9 \%$ (mean); $\mathrm{HT}_{4}(n=5) 18.5 \%$, and $\mathrm{HT}_{3}(n=3) 15.9 \%$. There was no evidence for a diurnal $(24 \mathrm{~h})$ variation in controls $(n=2), \mathrm{HT}_{4}(n=2)$, or $\mathrm{HT}_{3}(n=2)$ subjects. Their respective $\mathrm{CV}$ on data analyzed from frequent samples collected over $24 \mathrm{~h}$ were $14.9,22.6$, and $21.3 \%$.

Fig. 2 demonstrates that it is possible to maintain in an athyreotic subject the serum $T_{3}$ concentrations relatively stable over a $24-\mathrm{h}$ period with frequent small doses of $\mathrm{L}_{-} \mathrm{T}_{3}$. This was necessary to obtain steadystate $T_{3}$ kinetics studies in these subjects. The $\mathrm{CV}$ of $\mathrm{T}_{3}$ concentration in these samples was $11.9 \%$. The serum $3,3^{\prime}-\mathrm{T}_{2}$ concentration did vary somewhat more but, as reported above, the $\mathrm{CV}$ for the two $\mathrm{HT}_{3}$ cases studied over $24 \mathrm{~h}$ was $21.3 \%$, indicating reasonable stability. In the $\mathrm{HT}_{3}$ subjects (3) the serum $\mathrm{T}_{3} \mathrm{CV}$ was $12.6 \%$ over $8 \mathrm{~h}$.

Kinetics studies. The results of Sephadex column chromatographic analyses of one of the serum samples collected during the ${ }^{125} \mathrm{I}-3,3^{\prime}-\mathrm{T}_{2}$ infusion in one case are depicted in Fig. 3. Analysis of an aliquot of the infused dose is also shown. In the serum sample and in the infusate, ${ }^{125} \mathrm{I}-3,33^{\prime}-\mathrm{T}_{2}$ and iodide were the major labeled constituents. The zone between the ${ }^{125} \mathrm{I}^{-}$and ${ }^{125} \mathrm{I}-3,3^{\prime}-\mathrm{T}_{2}$ peaks contained a number of areas of low radioactivity. These peaks were considered to be metab-

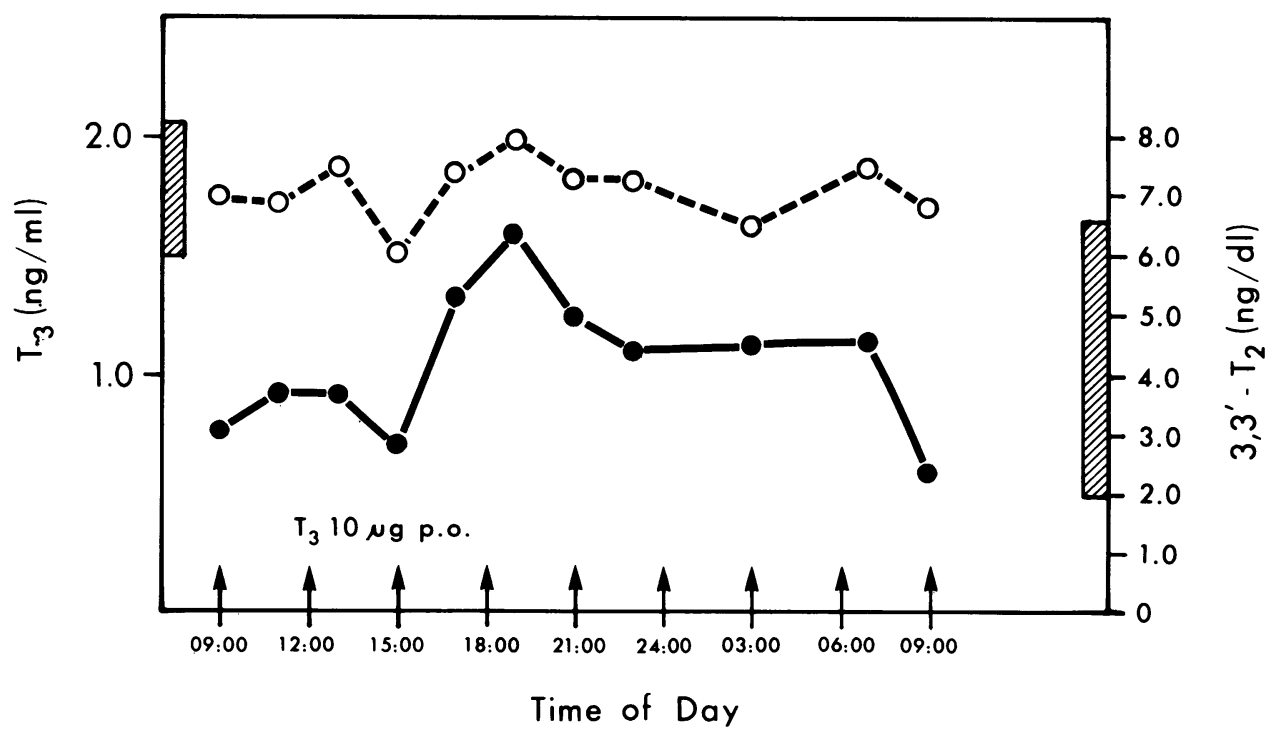

Figure 2 Serum concentrations during a 24-h period of $\mathrm{T}_{3}$ (interrupted line) and $3,3^{\prime}-\mathrm{T}_{2}$ (solid line) in a hypothyroid subject maintained eumetabolic on frequent oral doses (10 $\mu$ g every $3 \mathrm{~h}$ ) of $\mathrm{L}-\mathrm{T}_{3}$. The arrows (abscissa) indicate the dose times. On the left hand ordinate is the $\mathrm{T}_{3}$ concentration, and on the right hand ordinate, the $3,3^{\prime}-\mathrm{T}_{2}$ concentration. In each case, the hatched box indicates the mean $\pm 2 \mathrm{SD}$. 
olites of ${ }^{125} \mathrm{I}-3,3^{\prime}-\mathrm{T}_{2}$. The elution position of some of these metabolites, $3,3^{\prime}-\mathrm{T}_{2}$ conjugates and $3^{\prime}-\mathrm{T}_{1}$, was determined in separate column analyses. Fig. 3 also demonstrates that the elution profile of stable $3,3^{\prime}-\mathrm{T}_{2}$, added to the 6 -h sample before analysis on the Sephadex G-25 column, is superimposable on the ${ }^{125} \mathrm{I}-3,3^{\prime}-\mathrm{T}_{2}$ peak. This confirms the position of ${ }^{125} \mathrm{I}-3,3^{\prime}-\mathrm{T}_{2}$ in the eluted fractions from the column. In each subject studied at least two samples collected during the infusion period were analyzed to determine the ${ }^{125} I-3,3^{\prime}-T_{2}$ concentration.

The clearance of ${ }^{125} \mathrm{I}-3,3^{\prime}-\mathrm{T}_{2}$ was determined by the constant infusion method. In initial studies three separate serum samples collected during the interval from $2 \mathrm{~h}$ to the end of the infusion period were analyzed for ${ }^{125} \mathrm{I}-3,3^{\prime}-\mathrm{T}_{2}$. Fig. 4 shows that the concentration of ${ }^{125} \mathrm{I}-3,3^{\prime}-\mathrm{T}_{2}$ was relatively constant during this interval in all three cases, indicating that a steady state with respect to this tracer was achieved by the $2 \mathrm{nd} \mathrm{h}$ after infusion. (No priming dose was given.) The CV of the ${ }^{125} \mathrm{I}-3,3^{\prime}-\mathrm{T}_{2}$ concentration in these serum samples averaged $8.5 \%$. In the subsequent studies two serum samples collected during each infusion, usually at 4 and at $8 \mathrm{~h}$, were analyzed on the column. The ratio of the
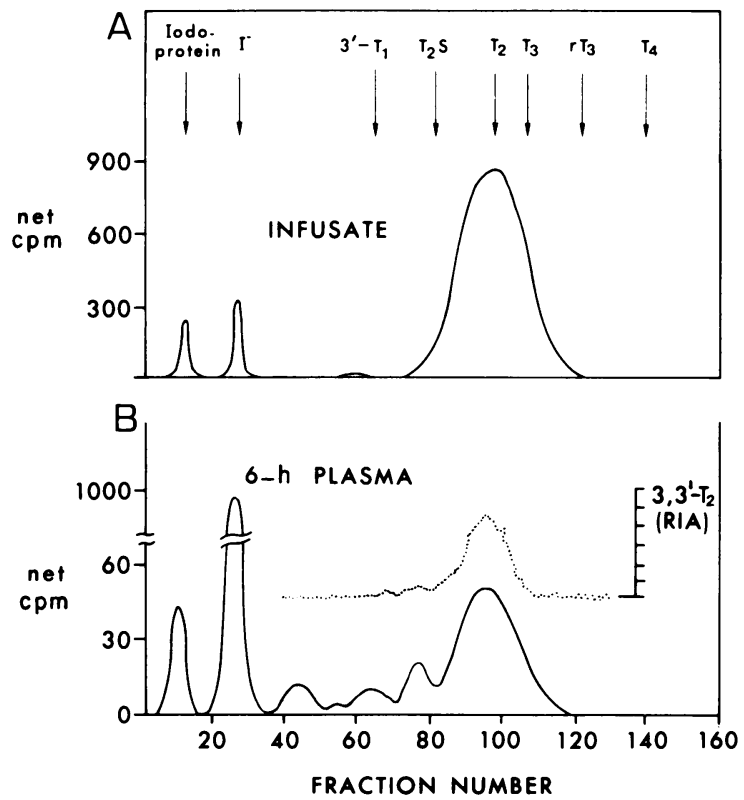

FIGURE 3 Column chromatographic analysis of radioactivity in an aliquot of the administered dose (infusate) of ${ }^{125} \mathrm{I}-3,3^{\prime}-\mathrm{T}_{2}$ (A) and in the 6-h plasma sample of a typical subject (B). (See text for details of the chromatographic method.) Arrows indicate position of $3,3^{\prime}-\mathrm{T}_{2}$ and other iodothyronines, $3^{\prime}$-monoiodothyronine $\left(3^{\prime}-T_{1}\right), 3,3^{\prime}-T_{2}$ conjugates $\left(T_{2} S\right), T_{3}, r_{3}$, and $\mathrm{T}_{4}$ determined on identical columns. The insert in the bottom panel (dotted line) indicates the elution profile of stable $3,3^{\prime}-\mathrm{T}_{2}$ added to the sample before column analysis and assayed by radioimmunoassay (RIA). Its position is superimposable on that of ${ }^{125} \mathrm{I}-3,3^{\prime}-\mathrm{T}_{2}$.

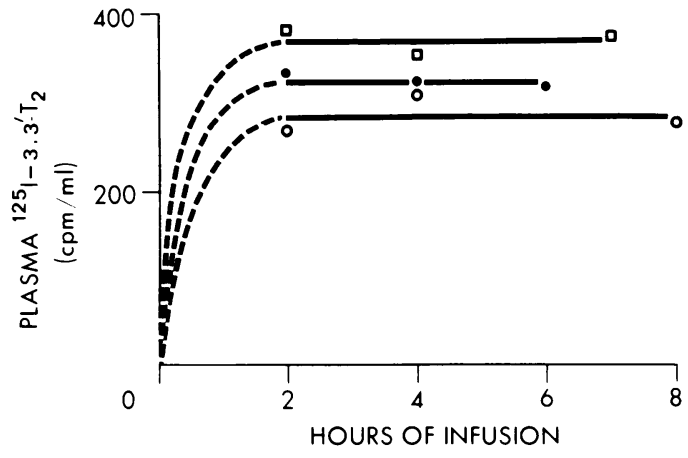

Figure 4 Constant infusion of ${ }^{125} \mathrm{I}-3,3^{\prime}-\mathrm{T}_{2}$ in three subjects. The plasma concentration of ${ }^{125} \mathrm{I}-3,3^{\prime}-\mathrm{T}_{2}$, in counts per minute per milliliter, is plotted on a linear scale (ordinate) against the duration of infusion in hours (abscissa). The figure indicates that the ${ }^{125} \mathrm{I}-3,3^{\prime}-\mathrm{T}_{2}$ concentration achieved a constant level within $2 \mathrm{~h}$. (No priming dose was given).

${ }^{125} \mathrm{I}-3,3^{\prime}-\mathrm{T}_{2}$ concentration in the final sample to that in the initial sample averaged $0.95 \pm 0.08$ in the entire group, again confirming that an isotopic steady state had been reached. In every case calculation of the clearance was based on the average of the ${ }^{125} \mathrm{I}-3,3^{\prime}-\mathrm{T}_{2}$ concentrations in all serum samples collected beyond the 2-h point of the infusion.

The plasma concentration of $3,3^{\prime}-\mathrm{T}_{2}$ and the kinetic parameters obtained in each of the subjects studied are shown in Table III. The mean total serum 3,3'- $\mathrm{T}_{2}$ concentration in the control (C) group $(n=7)$ was not significantly different from the $\mathrm{T}_{4}$-treated hypothyroid (H) group $(n=5)$. The mean total serum $\mathrm{T}_{4}$ concentrations and free $\mathrm{T}_{4}$ indices (normal $0.5-1.5$ ) were almost identical for the two groups, at $7.7 \pm 1.0 \mu \mathrm{g} / 100$ $\mathrm{ml} ; 0.9 \pm 0.2$ in $\mathrm{C}$, and $7.9 \pm 1.2 \mu \mathrm{g} / 100 \mathrm{ml} ; 0.9 \pm 0.3$ in $\mathrm{H}$, respectively. The $3,3^{\prime}-\mathrm{T}_{2} \mathrm{CR}$ averaged $628 \pm 218$ liters/day in $\mathrm{C}$ and $840 \pm 377$ liters/day in $\mathrm{H} .3,3^{\prime}-\mathrm{T}_{2}$ PR were not significantly different $(39.8 \pm 19.8 \mu \mathrm{g} /$ day in $\mathrm{C}$ vs. $33.9 \pm 12.5 \mu \mathrm{g} /$ day in $\mathrm{H}$ ).

To determine the quantitative significance of $3,3^{\prime}-\mathrm{T}_{2}$ as a product of the metabolism of $\mathrm{T}_{3}$ and $\mathrm{rT}_{3}$, the absolute turnover rates of $\mathrm{T}_{3}, \mathrm{rT}_{3}$, and $3,3^{\prime}-\mathrm{T}_{2}$ were determined in three athyreotic subjects on $T_{4}$ replacement. Table IV gives the kinetics studies results of each of these iodothyronines in the three subjects. The $3,3^{\prime}-T_{2} P R$ in each case was close to the combined $P R$ of $T_{3}$ and $r T_{3}$. The average ratio of $3,3^{\prime}-T_{2} P R$ (nanomoles per day) to the combined triiodothyronine PR (nanomoles per day) was $1.08 \pm 0.10$.

To estimate the magnitude of conversion of $T_{3}$ to $3,3^{\prime}-T_{2}$, kinetics studies were conducted on three athyreotic subjects receiving $\mathrm{L}_{\mathrm{S}} \mathrm{T}_{3}$ replacement at three or four hourly intervals. A single pulse injection of ${ }^{131} \mathrm{I}$ $\mathrm{T}_{3}$ and a constant 8-h infusion of ${ }^{125} \mathrm{I}-3,3^{\prime}-\mathrm{T}_{2}$ were given. The PR of each was determined as described above. Table $\mathrm{V}$ presents the $3,3^{\prime}-\mathrm{T}_{2}$ and $\mathrm{T}_{3}$ kinetics results 
TABLE III

Serum $T_{4}, 3,3^{\prime}-T_{2}$ Concentrations and Results of Kinetics Studies in Controls and $T_{4}$-Treated Hypothyroid Patients

\begin{tabular}{|c|c|c|c|c|c|c|c|}
\hline \multirow[b]{2}{*}{ Subject } & \multirow[b]{2}{*}{ Body wt. } & \multirow[b]{2}{*}{ Age } & & \multirow{2}{*}{$\begin{array}{c}\text { Serum } \\
T_{4}\end{array}$} & \multicolumn{3}{|c|}{$3,3^{\prime}-\mathrm{T}_{2}$} \\
\hline & & & & & Concn.* & CRt & PR \\
\hline Controls & $\mathrm{kg}$ & $y r$ & & $\mu g / d l$ & ng/liter & liters/day & $\mu g / d a y$ \\
\hline 1 & 68 & 57 & & 8.1 & 49 & 734 & 35.9 \\
\hline 2 & 85 & 59 & & 7.8 & 42 & 688 & 28.9 \\
\hline 3 & 95 & 53 & & 8.9 & 82 & 749 & 61.4 \\
\hline 4 & 82 & 30 & & 6.0 & 45 & 360 & 16.2 \\
\hline 5 & 77 & 47 & & 7.5 & 64 & 418 & 26.7 \\
\hline 6 & 66 & 31 & & 7.0 & 74 & 970 & 71.8 \\
\hline 7 & 67 & 30 & & 8.9 & 78 & 482 & 37.6 \\
\hline Mean & & & & 7.7 & 62 & 628 & 39.8 \\
\hline$\pm \mathrm{SD}$ & & & & \pm 1.0 & \pm 17 & \pm 218 & \pm 19.8 \\
\hline Treated hypo- & & & $T$, dose & & & & \\
\hline & & & $m g / d a y$ & & & & \\
\hline 8 & 88 & 62 & 0.150 & 8.3 & 46 & 912 & 41.9 \\
\hline 9 & 71 & 64 & 0.150 & 8.1 & 47 & 928 & 44.1 \\
\hline 10 & 76 & 79 & 0.125 & 6.5 & 31 & 1,374 & 42.6 \\
\hline 11 & 77 & 60 & 0.200 & 7.0 & 40 & 623 & 24.9 \\
\hline 12 & 79 & 64 & 0.100 & 9.5 & 45 & 366 & 16.5 \\
\hline Mean & & & & 7.9 & 42 & 840 & 33.9 \\
\hline$\pm \mathrm{SD}$ & & & & \pm 1.2 & \pm 7.0 & \pm 377 & \pm 12.5 \\
\hline
\end{tabular}

Concn., serum concentrations.

* Each value is the mean of six or more serum determinations of samples collected.

† Corrected to $70 \mathrm{~kg}$ body wt.

in each subject. The mean total serum $3,3^{\prime}-\mathrm{T}_{2}$ concentration $(3.4 \pm 1.2 \mathrm{ng} / 100 \mathrm{ml})$ was significantly lower than in the $C$ group $(6.0 \pm 1.0 \mathrm{ng} / 100 \mathrm{ml})(P<0.001)$. The $3,3^{\prime}-\mathrm{T}_{2} \mathrm{CR}$ averaged $653 \pm 144$ liters/day and the $3,3^{\prime}-\mathrm{T}_{2}$ PR, 22.6 $\pm 10.7 \mu \mathrm{g} / \mathrm{day}$. Although the latter value was not significantly less than the C group $(39.8 \pm 19.8 \mu \mathrm{g} /$ day), a study of a large number of $\mathrm{T}_{3}$-treated hypothyroid subjects could very well reveal a difference in $3,3^{\prime}-T_{2}$ PR compared to controls. The mean total serum $\mathrm{T}_{3}$ concentration was high $(1.53 \pm 0.28 \mathrm{ng} / 100 \mathrm{ml})$ in

TABLE IV

Serum $T_{3}, r T_{3}, 3,3^{\prime}-T_{2}$ Concentration and Results of Kinetics Studies in $T_{4}$-Treated Hypothyroid Patients

\begin{tabular}{|c|c|c|c|c|c|c|c|c|c|c|c|c|c|}
\hline \multirow{2}{*}{$\begin{array}{c}\text { Treated } \\
\text { hypo- } \\
\text { thyroids }\end{array}$} & \multirow[b]{2}{*}{ Body wt. } & \multirow[b]{2}{*}{ Age } & \multirow[b]{2}{*}{$T_{4}$ dose } & \multicolumn{3}{|c|}{$\mathrm{T}_{3}$} & \multicolumn{3}{|c|}{$\mathrm{rT}_{3}$} & \multicolumn{3}{|c|}{$3,3^{\prime}-T_{2}$} & \multirow{2}{*}{$\begin{array}{c}\left(3,3^{\prime}-T_{2} P R \S\right) / \\
\left(T_{3} P R+r T_{3} P R\right)\end{array}$} \\
\hline & & & & Concn.* & CR $\downarrow$ & PR & Concn.* & CRt & PR & Concn.* & CR $t$ & PR & \\
\hline & $k g$ & $y r$ & $m g / d a y$ & $\mu g / l i t e r$ & liters/day & $\mu g / d a y$ & $\mu g / l i t e r$ & liters/day & $\mu g / d a y$ & ng/liter & liters/day & $\mu g / d a y$ & \\
\hline 8 & 88 & 62 & 0.150 & 0.52 & 35.0 & 18.2 & 0.28 & 93.5 & 26.2 & 46 & 912 & 41.9 & 1.17 \\
\hline 9 & 71 & 64 & 0.150 & 0.78 & 29.0 & 22.6 & 0.28 & 117.0 & 32.8 & 47 & 928 & 44.1 & 0.98 \\
\hline 10 & 76 & 79 & 0.125 & 0.62 & 22.9 & 14.2 & 0.36 & 95.6 & 34.4 & 31 & 1,374 & 42.6 & 1.08 \\
\hline Mean & & & & $0.64^{\prime \prime}$ & 28.9 & 18.3 & 0.31 & 102.0 & 31.1 & 41.59 & $1,071 * *$ & 42.9 & 1.08 \\
\hline $\pm S D$ & & & & \pm 0.13 & \pm 6.1 & \pm 4.3 & \pm 0.05 & \pm 13.0 & \pm 4.4 & \pm 9.1 & \pm 262 & \pm 1.1 & \pm 0.10 \\
\hline
\end{tabular}

Concn., serum concentration.

* Each value is the mean of six or more serum determinations of samples collected during the kinetics studies.

t Corrected to $70 \mathrm{~kg}$ body wt.

$\$$ Nanomolar ratio of PR.

Significantly different from the control mean: " $(P<0.01)$, ๆ $(P<0.02),{ }^{* *}(P<0.02)$. 
comparison to the control subjects $(1.03 \pm 0.15 \mathrm{ng} / 100$ $\mathrm{ml})(P<0.001)$. Although the mean $\mathrm{T}_{3} \mathrm{CR}(33.0 \pm 4.3$ liters/day) was normal, the mean $\mathrm{T}_{3} \mathrm{PR}(50.9 \pm 13.8 \mu \mathrm{g} /$ day) was significantly higher $(P<0.005)$ than the previously reported normal value of $24.2 \pm 4.1 \mu \mathrm{g} /$ day (12). Table $\mathrm{V}$ also shows that the PR $\mathrm{T}_{3}$ in each subject was close to the daily dose of $\mathrm{L}_{-} \mathrm{T}_{3}$. It thus appears that almost $100 \%$ of the oral $T_{3}$ was absorbed. This finding agrees with previous studies (21).

The molar ratio of $3,3^{\prime}-T_{2}$ to $T_{3} P R$ varied among the three subjects from 0.36 to 0.92 , indicating that $3,3^{\prime}-T_{2}$ is an important product of $T_{3}$ deiodination.

\section{DISCUSSION}

The present study confirms the presence of $3,3^{\prime}-\mathrm{T}_{2}$ in normal human serum. The mean normal serum $3,3^{\prime}-\mathrm{T}_{2}$ concentration obtained in our study $(6.0 \pm 1.0 \mathrm{ng} / 100$ $\mathrm{ml}$ ) is intermediate between the value of $7.6 \pm 2.4 \mathrm{ng} /$ $100 \mathrm{ml}$ reported by $\mathrm{Wu}$ et al. (6), who employed ethanol extraction of serum and the recently reported value, $4.3 \pm 2.0 \mathrm{ng} / 100 \mathrm{ml}$, from Burger and Sakoloff (8), who analyzed unextracted serum. The presence of $3,3^{\prime}-T_{2}$ in normal whole serum at a slightly higher concentration $(17.0 \pm 1.0 \mathrm{ng} / 100 \mathrm{ml})$ measured by radioimmunoassay has also been reported by Burman et al. (7).

In hyperthyroidism, serum $3,3^{\prime}-\mathrm{T}_{2}$, like $\mathrm{T}_{4}, \mathrm{~T}_{3}$, and $\mathrm{rT}_{3}$, was elevated on the average. There was, however, a wide range of values from moderate elevation to markedly high serum $3,3^{\prime}-\mathrm{T}_{2}$ levels. The absence of a positive correlation between the serum total $\mathrm{T}_{4}$ and the $3,3^{\prime}-\mathrm{T}_{2}$ levels has been noted previously (22). It may be due to an increased $3,3^{\prime}-\mathrm{T}_{2} \mathrm{CR}$, as preliminary studies in our laboratory demonstrate increased $3,3^{\prime}-\mathrm{T}_{2}$ CR in hyperthyroidism (23). The normal serum $3,3^{\prime}-T_{2}$ levels in patients with elevated TBG concentration is consistent with the reported low binding affinity of $3,3^{\prime}-T_{2}$ for TBG, compared with $T_{4}(24)$, and normal levels in pregnancy (6).
The finding of normal serum 3,3'- $T_{2}$ levels in athyreotic subjects maintained eumetabolic on $\mathrm{T}_{4}$ replacement confirms a previous report (22) and suggests that the major source of circulating $3,3^{\prime}-\mathrm{T}_{2}$ is extrathyroidal production.

The original analysis of rat thyroglobulin by Roche et al. (1) suggested that $3,3^{\prime}-T_{2}$ was a major component of the iodothyronines present. This finding in the rat was not confirmed by the recent studies of Taurog et al. (25), who demonstrated that $3,3^{\prime}-\mathrm{T}_{2}$ comprised $<2 \%$ of the total ${ }^{131} \mathrm{I}$ in the thyroids of severely iodinedeficient rats and even less in the iodine-replete animal. In a recent report Burman et al. (7) found a 3,3'- $T_{2}$ concentration of $0.4 \pm 0.03 \mu \mathrm{g} / \mathrm{g}$ in normal thyroid tissue and a lack of a serum $3,3^{\prime}-T_{2}$ response secondary to thyrotropin-releasing hormone stimulation, findings indicative of a minimal rate of thyroidal secretion. That the thyroid gland is not a major source of circulating $3,3^{\prime}-T_{2}$ is confirmed by the similar $3,3^{\prime}-T_{2} P R$ in the euthyroid control group and in the athyreotic subjects in whom the only source of $3,3^{\prime}-T_{2}$ was exogenous $T_{4}$. There are no other data available at present to compare with the PR of $3,3^{\prime}-T_{2}$ obtained in this study.

The rate of disappearance from the blood of tracer $3,3^{\prime}-\mathrm{T}_{2}$ (as the racemic mixture) in man has been examined in a previous study and found to be extremely rapid (9). The achievement of a constant plasma level of ${ }^{125} \mathrm{I}-3,3^{\prime}-\mathrm{T}_{2}$ during the first few hours of a constant infusion is consistent with this finding. However, quantitative estimates of 3,3'- $T_{2}$ CR have not been reported previously.

The metabolism of $3,3^{\prime}-\mathrm{T}_{2}$ would be expected to yield monoiodothyronines, thyronine itself, deaminated derivatives, and conjugated forms. The glucuronic acid conjugate of $3,3^{\prime}-T_{2}$ has been identified in the bile of the rat after the injection of labeled $3,3^{\prime}-T_{2}$ (26) and the sulfate conjugate of $3,3^{\prime}-\mathrm{T}_{2}$ in the bile and urine of the dog after the administration of labeled $T_{3}$ (16). Stanbury and Morris (9) demonstrated

TABLE V

Serum $T_{3}, 3,3^{\prime}-T_{2}$ Concentration and Results of Kinetic Studies in $T_{3}$ Treated Hypothyroid Subjects

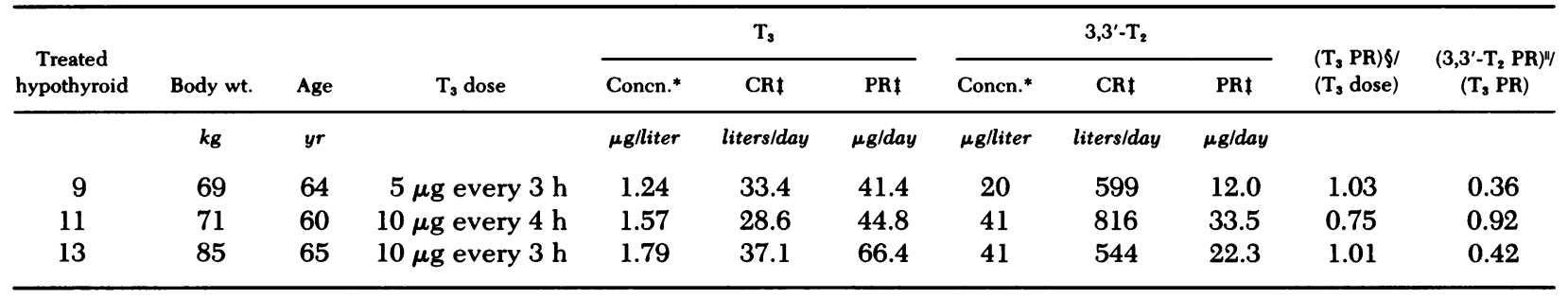

Concn., serum concentration.

* Each value is the mean of six or more serum determinations on samples collected during the kinetics studies.

‡ Corrected to $70 \mathrm{~kg}$ body wt.

$\S$ Uncorrected for body wt.

"Nanomolar ratio of PR. 
the presence of two unidentified compounds in some serum samples chromatographed after the administration of ${ }^{131} \mathrm{I}-3,3^{\prime}-\mathrm{T}_{2}$. The Sephadex column employed in the present study separates $3,3^{\prime}-\mathrm{T}_{2}$ conjugates and $3^{\prime}$ $\mathrm{T}_{1}$ from $3,3^{\prime}-\mathrm{T}_{2}$. Even if the $3,3^{\prime}-\mathrm{T}_{2}$-containing fractions from our columns did include labeled metabolites, however, the calculated CR would have underestimated the true CR in our subjects.

The magnitude of $3,3^{\prime}-T_{2}$ PR suggests that it is a major metabolite of the deiodination pathways. Tracer studies in both the rat $(2,27,28)$ and the $\operatorname{dog}(4,16)$ demonstrated that both $\mathrm{T}_{3}$ and $\mathrm{rT}_{3}$ are precursors of $3,3^{\prime}-\mathrm{T}_{2}$.

Recent in vitro studies by Chopra et al. (5) in rat liver homogenates have demonstrated that both $\mathrm{T}_{3}$ and $\mathrm{rT}_{3}$ are converted to $3,3^{\prime}-\mathrm{T}_{2}$. The finding of $5^{\prime}$-deiodination (phenolic ring) of $\mathrm{rT}_{3}$ to $3,3^{\prime}-\mathrm{T}_{2}$ by liver homogenates confirms the previous reports by Flock and Owen (29) who employed perfused rat liver and a recent study of the metabolism of thyroid hormones by cultured monkey hepatocarcinoma cells (30).

There has been no information, however, on the quantitative significance of $3,3^{\prime}-\mathrm{T}_{2}$ as a metabolite of $\mathrm{T}_{3}$ or $\mathrm{rT}_{3}$ until the present study in humans. The magnitude of $3,3^{\prime}-T_{2}$ PR indicates that it is a major metabolite of both triiodothyronines. In all cases studied, the 3,3'$\mathrm{T}_{2} \mathrm{PR}$ was close to the combined $\left(\mathrm{T}_{3}+\mathrm{RT}_{3}\right) \mathrm{PR}$, accounting for $90-110 \%$ of total turnover. This finding is supported by the demonstration that the conversion of $\mathrm{T}_{3}$ to $3,3^{\prime}-\mathrm{T}_{2}$ (in $\mathrm{T}_{3}$-replaced subjects) was a major pathway of $\mathrm{T}_{3}$ metabolism.

The finding that both $\mathrm{T}_{3}$ and $\mathrm{rT}_{3}$ are major precursors of $3,3^{\prime}-T_{2}$ and that the magnitude of their contribution may be variable could explain the observation of a normal serum 3,3'- $T_{2}$ concentration in acute nonthyroidal systemic illness with low serum $\mathrm{T}_{3}$ but high serum $\mathrm{rT}_{3}$.

Previous studies in normal humans have demonstrated that 5-deiodination of $\mathrm{T}_{4}$ to $\mathrm{rT}_{3}$ is at least as active as $5^{\prime}$-deiodination to $T_{3}$, the total activity of both pathways accounting for most of the $T_{4}$ metabolized $(12,31)$. The present finding that $3,3^{\prime}-\mathrm{T}_{2}$ is the principal product of the metabolism of both $\mathrm{rT}_{3}$ and $\mathrm{T}_{3}$ indicates the importance of $3,3^{\prime}-T_{2}$ as an intermediate in $T_{4}$ metabolism. Furthermore, the finding implies that the other diiodothyronines, $3,5-\mathrm{T}_{2}$ and $3^{\prime}, 5^{\prime}-\mathrm{T}_{2}$, are of only minor quantitative significance.

Early studies by Roche et al. (1) demonstrated that $3,3^{\prime}-\mathrm{T}_{2}$ was calorigenically active but this has not been confirmed by subsequent in vivo studies $(25,32-34)$. Recent studies have shown the ability of $3,3^{\prime}-\mathrm{T}_{2}$ to enhence the uptake of radioleucine by thymocytes in culture, but the effect was seen only at high concentrations and so its biological significance is not clear (35). Even if it is not biologically active, 3,3'- $\mathrm{T}_{2}$ must be regarded as a major intermediate in the deiodination of iodothyronines. A recent report by Chopra (36) shows that $3,3^{\prime}-\mathrm{T}_{2}$ is a weak inhibitor of the conversion of $T_{4}$ to $T_{3}$ in rat liver homogenates. This raises the possibility that $3,3^{\prime}-\mathrm{T}_{2}$ may regulate the monodeiodination of $\mathrm{T}_{4}$. Studies are presently in progress in our laboratory to elucidate further the significance of this intermediate in the peripheral metabolism of iodothyronines.

\section{ACKNOWLEDGMENTS}

The authors are deeply grateful to Dr. Orlo H. Clark for the preparation of ${ }^{125}$ I-labeled rat bile used in this study; Dr. Franco Bui (supported by Fondazione Anna Villa Rusconi) for his excellent assistance, to the staff of the Metabolic Ward (Specialized Diagnostic and Treatment Unit) for invaluable assistance in human studies, and Ruth Miller for her secretarial assistance.

This work was supported by the Medical Research Service of the Veterans Administration.

\section{REFERENCES}

1. Roche, J., R. Michel, W. Wolf, and J. Nunez. 1956. Sur deux nouveaux constituents hormonaux du corps thyroide: la 3-3'-diiodothyronine et $3,3^{\prime}, 5^{\prime}$-triiodothyronine. Biochim. Biophys. Acta. 19: 308-317.

2. Roche, J., R. Michel, J. Nunez, and C. Jocquemin. 1959. On the metabolism of 3,3'-diiodothyronine and 3,3',5'triiodothyronine. Endocrinology. 65: 401-407.

3. Flock, E. V., J. E. Bollman, and J. R. Grindlay. 1960. Conjugates of triiodothyronine and its metabolites. Endocrinology. 67: 419-429.

4. Flock, E. V., C. David, G. H. Stobie, and C. A. Owen. 1963. 3,3',5'-Triiodothyronine and 3,3'-diiodothyronine: partially deiodinated intermediates in the metabolism of the thyroid hormones. Endocrinology. 73: 442-455.

5. Chopra, I. J., S. Y. Wu, and D. Solomon. 1976. Extrathyroidal production of 3,3'-diiodothyronine $\left(\mathrm{T}_{2}\right)$ in vitro: $A$ major pathway of reverse- $T_{3}$ metabolism and minor pathway for $\mathrm{T}_{3}$. 58th Annual Meeting of Endocrine Society. 102. (Abstr.)

6. Wu, S. Y., I. J. Chopra, Y. Nakamura, D. Solomon, and L. R. Bennett. 1976. A radioimmunoassay for measurement of 3,3'-L-diiodothyronine $\left(\mathrm{T}_{2}\right)$. J. Clin. Endocrinol. Metab. 43: 682-685.

7. Burman, K. D., D. Strum, R. C. Dimond, Y. Y. Djuh, F. D. Wright, J. M. Earll, and L. Wartofsky. 1977. A radioimmunoassay for 3,3'-L-diiodothyronine $\left(3,3^{\prime}-\mathrm{T}_{2}\right)$. J. Clin. Endocrinol. Metab. 45: 339-353.

8. Burger, A., and C. Sakoloff. 1977. Serum 3,3'-L-diiodothyronine, a direct radioimmunoassay in human serum, method and clinical results. J. Clin. Endocrinol. Metab. 45: 384-391.

9. Stanbury, J. B., and M. L. Morris. 1957. The metabolism of 3,3'-diiodothyronine in man. J. Clin. Endocrinol. Metab. 17: 1324-1331.

10. Gharib, H., R. J. Ryan, W. E. Mayberry, and T. Hockert. 1971. Radioimmunoassay for triiodothyronine $\left(T_{3}\right)$ : affinity and specificity of the antibody for $\mathrm{T}_{3}$. J. Clin. Endocrinol. Metab. 33: 509-516.

11. Larsen, P. R. 1972. Direct immunoassay of triiodothyronine in human serum. J. Clin. Invest. 51: 1939-1949.

12. Gavin, L. A., J. N. Castle, F. A. McMahon, P. Martin, M. E. Hammond, and R. R. Cavalieri. 1977. Extrathyroidal 
conversion of thyroxine to $3,3^{\prime}, 5^{\prime}$-triiodothyronine (reverse- $\left.\mathrm{T}_{3}\right)$ and to $3,5,3^{\prime}$-triiodothyronine $\left(\mathrm{T}_{3}\right)$ in humans. J. Clin. Endocrinol. Metab. 44: 733-742.

13. Abreau, C., A. Vagenakis, F. Azizi, G. Portnay, and L. Braverman. 1973. A single method for measuring total thyroxine and free thyroxine in serum. J. Nucl. Med. 14: $740-742$.

14. Shen, N. H., M. B. Katzman, F. E. Francis, and R. A. Kinsella. 1963. Determination of pregnanolone, pregnanediol and pregnanetriol in urine. J. Lab. Clin. Med. 61: $174-182$.

15. De Forrest-Abbott, L. 1947. Phenolsulfatase activity. Arch. Biochem. Biophys. 15: 205-214.

16. Flock, E. V., J. E. Bollman, and J. H. Grindlay. 1960. 3,3'-diiodothyronine, a metabolite of 3,5,3'-triiodothyronine. Proc. Staff Meetings Mayo Clin. 35: 75-81.

17. Green, W. H. 1972. Separation of iodo-compounds in serum by chromatography on Sephadex columns. J. Chromatogr. 72: 83-91.

18. Nicoloff, J. T., J. C. Low, J. H. Dussault, and D. A. Fisher. 1972. Simultaneous measurement of thyroxine and triiodothyronine peripheral turnover kinetics in man. $J$. Clin. Invest. 51: 473-483.

19. Tait, J. F. 1963. Review: the use of isotopic steroids for the measurement of production rates in vivo.J. Clin. Endocrinol. Metab. 23: 1285-1297.

20. Snedecor, G. W., and W. G. Cochran. 1967. Statistical Methods. Iowa State University Press, Ames, Iowa. 6th edition. 91-119.

21. Hayes, M. T. 1970. Absorption of triiodothyronine in man. J. Clin. Endocrinol. Metab. 30: 675-677.

22. Burman, K. D., R. C. Dimond, R. A. McGuire, J. M. Earll, D. Strum, and L. Wartofsky. 1976. The effects of varying serum $\mathrm{T}_{4}$ concentration on extrathyroidal production of $\mathrm{T}_{3}$, reverse $\mathrm{T}_{3}$ and $3,3^{\prime}$-diiodothyronine $\left(3,3^{\prime}-\mathrm{T}_{2}\right)$ Clin. Res. 24(3): 270A. (Abstr.)

23. Gavin, L. A., M. E. Hammond, J. N. Castle, and R. R. Cavalieri. 1977. 3,3'-diiodothyronine production, a major pathway of peripheral iodothyronine metabolism in man. Clin. Res. 25(3): 294A. (Abstr.)

24. Snyder, S. M., R. R. Cavalieri, I. D. Goldfine, S. H. Ingbar, and E. C. Jorgensen 1976. Binding of thyroid hormones and their analogues to thyroxine-binding globulin (TBG) in human serum. J. Biol. Chem. 251: 6489-6494.

25. Taurog, A., G. Riese, and P. R. Larsen. 1976. Formation of 3,3'-diiodo-thyronine and 3,3',5-triiodothyronine (reverse- $\mathrm{T}_{3}$ ) in thyroid glands of rats and in enzymatically iodinated thyroglobulin. Endocrinology. 99: 281-290.

26. Roche, J., R. Michel, J. Nunez, and N. Etling. 1955. Sur le metabolism de la dl-3,3'-diiodothyronine et sur le role de celle-ci en tant qu'-hormone thyroidienne. C. $R$. Seances Soc. Biol. Fil. 149: 1215-1219.

27. Roche, J., R. Michel, P. Jouan, and W. Wolf. 1956. The recovery of 3,5,3'-triiodothyroacetic acid and 3,3' diiodothyronine from rat kidney after injection of 3,5,3'-triiodothyronine. Endocrinology. 59: 425-432.

28. Roche, J., R. Michel, and P. Jouan. 1956. The presence of 3,5,3'-triiodothyroacetic acid and 3,3'-diiodothyronine in rat muscle after the injection of L-3,5,3'-triiodothyronine. Bull. Soc. Clin. Biol. 38: 941-950.

29. Flock, E. V., and C. A. Owen. 1965. Metabolism of thyroid hormones and some derivatives in isolated, perfused rat liver. Am. J. Physiol. 209: 1039-1045.

30. Sorimachi, K., and J. Robbins. 1977. Metabolism of thyroid hormones by cultured monkey hepato carcinoma cells. J. Biol. Chem. 252: 4458-4463.

31. Chopra, I. J. 1976. An assessment of daily production and significance of thyroidal secretion of $3,3^{\prime}, 5^{\prime}$-triiodothyronine (reverse $\mathrm{T}_{3}$ ) in man. J. Clin. Invest. 58: 32-40.

32. Gemmill, C. L. 1956. Metabolic activity of 3,3'-diiodothyronine and 3,3'-diiodo-5-6 bromothyronine. Am. J. Physiol. 186: 1-5.

33. Stasilli, N. R., R. L. Kroc, and R. I. Meltzer. 1959. Antigoitrogenic and calorigenic activities of thyroxine analogues in rats. Endocrinology. 64: 62-125.

34. Money, W. L., S. Kumaoka, and R. W. Rawson. 1960. Metabolic effects of thyroid hormones and their analogues Ann. N. Y. Acad. Sci. 86: 512-544.

35. Goldfine, I. D., G. T. Smith, C. G. Simons, S. H. Ingbar, and E. C. Jorgensen. 1976. The activities of thyroid hormones and related compounds in an in vitro thymocyte assay. J. Biol. Chem. 251: 4233-4238.

36.. Chopra, I. J. 1977. A study of extrathyroidal conversion of thyroxine $\left(\mathrm{T}_{4}\right)$ to 3,3 ,5-triiodothyronine $\left(\mathrm{T}_{3}\right)$ in vitro. Endocrinology. 101: 453-463. 